NBER WORKING PAPER SERIES

\title{
WHY CHINA IS LIKELY TO ACHIEVE ITS GROWTH OBJECTIVES
}

\author{
Robert W. Fogel \\ Working Paper 12122 \\ http://www.nber.org/papers/w12122 \\ NATIONAL BUREAU OF ECONOMIC RESEARCH \\ 1050 Massachusetts Avenue \\ Cambridge, MA 02138 \\ March 2006
}

I have benefitted from discussions at the CES meeting, seminars at the University of Illinois Chicago, the University of Chicago, and Northwestern University, and from suggestions by AJ Aiseirithe, Louis Cain, Thomas Chappelear, Jack Goldstone, James Heckman, Justin Lin, and Werner Troesken. The views expressed herein are those of the author(s) and do not necessarily reflect the views of the National Bureau of Economic Research.

(C2006 by Robert W. Fogel. All rights reserved. Short sections of text, not to exceed two paragraphs, may be quoted without explicit permission provided that full credit, including $\odot$ notice, is given to the source. 
Why China is Likely to Achieve its Growth Objectives

Robert W. Fogel

NBER Working Paper No. 12122

March 2006

JEL No. O0

\begin{abstract}
In 2002, the Chinese Communist Party announced a goal of quadrupling per capita income by the year 2020. Starting at income levels of the year 2000, this would require a growth rate of 7.2 percent per annum in per capita income or close to 8.0 percent in GDP. Such unresolved and emerging problems as growing income disparities, increasing pollution, pressures on infrastructure, the inefficiency of state owned enterprises, and political instability are often cited as reasons to doubt the attainability of the CCP's goal. However, China's progress in addressing fundamental constraints that might limit rapid economic growth augurs well for the success of its economic goals. Although there are disagreements about economic policy among top leaders, the continued transformation into a market economy and the promotion of increasing local autonomy in economic matters are not in doubt. In education, China has substantially increased the percentage of its workforce receiving a college education, and continuing growth in this investment in human capital could account for a large portion of the desired growth rate. In addition, the value of improvements in the quality of economic output unmeasured by GDP, such as advances in the quality of health care and education, could raise reported growth rates by as much as 60 percent. Finally, the government's increasing sensitivity to public opinion and issues of inequality and corruption, combined with improving living conditions, have resulted in a level of popular confidence in the government that makes political instability unlikely.

Robert W. Fogel

The University of Chicago

Graduate School of Business

5807 South Woodlawn Avenue

Chicago, IL 60637

and NBER

rwf@cpe.uchicago.edu
\end{abstract}




\section{Why China Is Likely to Achieve Its Growth Objectives}

In 2002, the Chinese Communist Party announced a goal of quadrupling per capita income by the year 2020. Starting at income levels of the year 2000, this would require a growth rate of 7.2 percent per annum in per capita income or close to 8.0 percent in GDP (M. Wang 2005). Is China likely to meet that objective? That question has been a subject of debate in Asia, Europe, and America, with an array of both pessimistic and optimistic views.

In this paper I present some reasons for joining the optimists. Indeed, I will argue that China's GDP is likely to grow at rates of 8 percent per annum or more for a least a generationthat is, to 2030 — and perhaps beyond that date. Before getting into substantive issues about the economic, structural, and political problems that will have to be overcome if the growth objectives are to be met, it is useful to look at some numbers in order to set the context for analysis.

Exceptionally rapid rates of growth have been achieved by several poor Asian countries for relatively long stretches of time since World War II. During the twenty years from 1950 to 1970, Japan grew at an average annual rate of 8.4 percent in per capita income, increasing its per capita income more than sixfold, an achievement that is 50 percent higher than the goal set by the Chinese leadership. Over the twenty years between 1960 and 1980, Singapore's growth in per capita income averaged 7.3 percent. The corresponding figure for South Korea between 1965 and 1985 was 7.6 percent, and Taiwan-China averaged 7.2 percent over the same period. Even China exceeded its new growth target over the 22-year period from 1980 to 2002, when the achieved growth rate averaged 8.2 percent per annum (Fogel 2004b). So the target set by the leadership is well within the experience of the rapidly growing economies of Southeast Asia. 
However, those who question whether the new goal is achievable do so not because they are unaware of the past experience of nations within the region, but because they doubt that China will be able to replicate the experience of past leaders between now and 2020. The doubts arise from beliefs that unresolved or emerging economic, political, and international problems are likely to reduce the recent growth rate substantially. One of the economic issues is the shaky state of the banking system, which is saddled with a high proportion of nonperforming loans. The inefficiency and unprofitability of many state-owned enterprises (SOEs) is also seen as a threat to future growth. Another problem is the growth in income disparities between the rapidly growing coastal provinces and the more slowly growing interior provinces, between urban and rural labor, and between highly skilled and manual labor (cf. Heckman 2005). There are also bottlenecks in infrastructure, including pressure on fuel supplies and electrical power, and the growth of environmental pollution. Although concern over the capacity of China to feed itself has diminished, concern over the adequacy of water supplies has risen. This is not an exhaustive list of the potential economic impediments to a continued high rate of economic growth, but it captures some of the main concerns. ${ }^{1}$

Although I recognize the importance of these issues, I shall not dwell on them at this point. I view them as issues that need to be addressed during the course of economic growth and, for reasons that I discuss in the second half of the paper, I believe that they will be addressed. They are certainly on the "to do" lists of China's political leaders and their economic advisors, who stress the need for reducing social and economic imbalances. My initial focus is on more fundamental constraints to sustaining rapid economic growth for another generation, constraints that might undermine long-term growth prospects even if all the right things are done to resolve the current litany of problems. 
To get at these potentially more binding constraints it is useful to disaggregate the sources of growth in per capita income between 1978 and 2002. The process is facilitated by equations (1) and (2) in Figure 1. Equation (1) is merely an identity which states that the level of per capita income is equal to output per worker multiplied by the labor force participation rate. In equation (1) the output of the economy is divided into three sectors: agriculture, industry, and services. Labor productivity in each sector is weighted by that sector's share of the labor force. Equation (2) is the rate of growth transformation of equation (1). It says that the rate of growth in per capita income is a weighted average of the sum of the rate of change in the labor share and of labor productivity of each sector plus the rate of change in the labor force participation rate. The sectoral weights are the mid-period shares of income originating in each sector.

Table 1 shows that 69 percent of the growth in per capita income between 1978 and 2002 was due to increases in labor productivity within each of the three main sectors of the economy. ${ }^{2}$ The rise in labor productivity was most rapid in industry (6.2 percent per annum) despite the inefficient state-owned enterprises and the inefficiencies in the allocation of capital. As Lin and Tsai (2004, 355-356) have pointed out, the policy of gradually shifting from central control appears to have been more effective than the "big bang" approach. By sequencing reforms that successively enlarged the scope of the market sector, even the SOEs shifted most of their purchases and sales to market prices rather than plan prices.

Table 1 also shows that while changes in labor productivity were highest in the industrial sector, they were nearly as high in agriculture (5.7 percent in agriculture as compared to 6.2 percent in industry). Moreover, this high rate of growth in agricultural productivity has been sustained for more than two decades. Table 2 shows that although China's rate of growth in agricultural labor productivity over a two-decade period is not unprecedented, it is at the high 
end of experience in both Asia and Europe. Only Korea exceeded the Chinese growth in agricultural labor productivity between 1980 and 1997, but in contrast to China, most of the Korean agricultural labor force had already shifted into industry and services. In the Chinese case, half of the labor force is still in agriculture, so the interindustry effect might yet prove to be substantial. Indeed, it is likely to be somewhat larger in the next two decades than it was between 1980 and 2000.

Since about 30 percent of China's growth rate is likely to continue to come from interindustry shifts and modest increases in the labor force participation rate (cf. Johnson 2000), growth rates of labor productivity within sectors need only average about 5 percent per year. Several factors suggest that such growth rates are likely. Despite the remarkable advances of recent decades, the average technology is still well below best prevailing practice in each of the three sectors. Hence, growth in each sector will be stimulated by the diffusion of the best prevailing practice. Moreover, the frontier of technology is moving out rapidly, especially in the industrial and service sectors, but also in agriculture. Third, the investment in capital, especially human capital, is capable of rapid improvement in the next several decades. Finally, despite the preoccupation with possible overstatement of the Chinese growth rate due to inflated estimates of growth sent from localities, on balance it is likely that the true Chinese growth rate is understated, especially in the service sector, due to the failure adequately to account for improvements in the quality of output and the underreporting of small firms. I now want to elaborate briefly on these last two factors and assess their likely impact on growth rates over the next two or three decades. 


\section{The Role of Factor Enhancement}

Table 3 presents enrollment ratios in primary, secondary, and tertiary schools for 1980 , 1990, 1997, and 2000. China is compared with seven Asian nations, four Western European nations, and the United States. At the primary level, China's ratios exceed those of all the other nations. At the secondary level China compares favorably with the other newly industrializing countries (NICs), but it is behind South Korea, Japan, Western Europe, and the United States. However, the gap diminished rapidly between 1990 and 1997. In this brief span the enrollment ratio at the secondary level increased by over 40 percent. China lags furthest behind the rich nations at the tertiary level. There its enrollment level is between 15 and 27 percent of enrollment levels in Korea, Japan, Western Europe, and the United States. However, once again it is rapidly closing the gap. Between 1990 and 2004 the Chinese tertiary enrollment ratio sextupled (China Statistical Yearbook 2005).

It is possible to quantify the impact of enhancing the quality of labor through education on the growth rate of per capita income by making use of the equations shown in Figure 2. Equation (3) is a factor-augmenting production function in which $\gamma_{L}$ and $\gamma_{K}$ are indexes of labor and capital augmentation (in this discussion I will focus only on labor augmentation). Equation (4) merely rearranges equation (3) to put it in a more convenient form. The dependent variable is now labor productivity and the term in square brackets brings the augmentation indexes together with the index of total factor productivity. Equation (5) is the rate of growth transformation of equation (4). It indicates that when all other variables are held constant, labor productivity will grow at the rate of growth of labor augmentation multiplied by labor's share in income. 
Table 4 presents the information needed to implement equation (5). The top part presents an index of the relative productivity of labor with primary, high school, and college degrees. The index is based on the income of U.S. males by education level. It indicates that a collegeeducated worker is 3.1 times as productive, and a high school graduate is 1.8 times as productive, as a worker with less than a ninth-grade education. ${ }^{3}$ The bottom half of the table indicates the contribution of various scenarios of increases in enrollment ratios. Labor enhancement would grow at the rate of 1.8 percent per annum if the secondary ratio reached one hundred in 20 years. Multiplying this figure by the labor share indicates that such an achievement would add about 1.1 percent to the growth rate of labor productivity.

Labor enhancement would grow at 7.4 percent per annum if the tertiary ratio rose from 6 to 25 in the next twenty years, which would put the tertiary level of education in China at about where the Western European nations were in 1980. That level of labor augmentation would add 4.4 percent to the growth rate of labor productivity, and by itself would account for over 60 percent of the target set in 2002. With a more ambitious expansion of higher education, reaching enrollment ratios of 50 in 20 years, labor augmentation would grow at 11.2 percent. The rate of investment in human capital would by itself add 6.7 percent to the overall growth rate.

These targets for higher education are not out of reach. It should be remembered that as recently as 1980, the Western European nations had ratios of about 25. Only the United States was above 50. The movement to enrollment ratios of 50 in Western Europe was a product of the last two decades of the twentieth century. In the case of the U.K., two-thirds of the increase from 19 to 52 percent took place between 1990 and 1997.

The significance of investment in human capital as an engine of economic growth has not eluded the State Council. In 1998 Jiang Zemin called for a massive increase in enrollments in 
higher education. The response was swift: over the next four years enrollment in higher education increased by 165 percent (from 3.4 million to 9.0 million) and the number of students studying abroad also rose by 152 percent (China Statistical Yearbook 2003). It is currently estimated that by 2010 at least 20 percent of high school graduates will be enrolled in institutions of higher education and the long run target is 50 percent by 2050 . The tertiary enrollment ratio increased by about 50 percent between 2000 and 2004 (from 12.5 to 19.0 percent), so the calculations shown in Table 4 may well be too conservative (China Statistical Yearbook 2005). China currently has about 20 million students enrolled in higher education, which exceeds current U.S. enrollments by about 60 percent. (Newcomb 2005; U.S. Statistical Abstract 2005). It is estimated that in 2005-6 China will produce 3.3 million college graduates, India 3.1 million, and the United States 1.3 million (Colvin 2005). However, in advancing the frontier of scientific training, the United States still has a considerable lead.

\section{Errors in the Measurement of Output}

So far I have focused mainly on factor enhancement to support my contention that China is likely to achieve its growth targets. I want to turn now to the problems of measurement on the output side of equation (5). Errors in the measurement of national income from the output side have become increasingly severe. It is now clear that official estimates of GDP for the United States badly underestimate U.S. economic growth because they do not take into account improvements in the quality of output, especially in such services as education and health care. Children in secondary schools are taught more about science and technology today than postgraduate college students used to be taught a generation ago, let alone two generations ago.

Even more dramatic are the improvements in health care. A century and a half ago, people in their late thirties and early forties were more afflicted by chronic disabilities than 
people in their late sixties and early seventies are today. Not only has the average age at onset of disabilities been delayed by a decade or so, but once disabilities appear, there are now numerous effective interventions. Hernias, which used to be permanent and exceedingly painful conditions afflicting one out of every four males, can now be repaired by a surgical procedure that in the United States requires hospitalization for only 23 hours. Other areas where medical interventions have been highly effective include treatment of genito-urinary conditions, control of hypertension and reduction in the incidence of stroke, replacement of knee and hip joints, curing of cataracts, and chemotherapies that reduce the incidence of osteoporosis and heart disease (Fogel 2004a).

Yet most of these great advances in health care and education are overlooked in the GDP accounts, because the values of these sectors are measured by inputs instead of by output. An hour of a doctor's time is considered no more effective today than an hour of a doctor's time was half a century ago, before the age of antibiotics and modern surgery. It has recently been estimated that the value of improvements in health care, if properly measured, are at least twice the cost of health care, but such calculations have not yet made their way into the GDP accounts (Cutler and McClellan 2001; Murphy and Topel 2003; Nordhaus 2003). In the case of the United States, my own rough estimates indicate that allowing for such factors as the increase in leisure time, the improvement in the quality of health care, and the improvements in the quality of education would come close to doubling the U.S. annual growth rate of per capita income over the past century (from 2.0 to 3.6 percent per annum).

What is the implication of these statistics for understanding the change in standards of living for the typical American? If we use the conventional measure of growth, the real income of the typical American in 2000 was 7 times greater than it was in 1900. However, if an adjusted 
measure is used, Americans in 2000 had real incomes that were 34 times greater than in 1900. In other words, 80 percent of the goods and services that Americans enjoy today are outside of the measured economy (Fogel 2000 and 2004a).

What is the implication of the failure to take account of improvements in the quality of output for the measurement of Chinese economic growth? In China the main increases in life expectancy took place before the onset of the period of reform. Between 1950 and 1980, life expectancy at birth increased from 40.8 to 67.8 years. By 2000 life expectancy stood at about 71.4 , an increase of about 0.18 years of life expectancy per calendar year during the period of accelerated economic reform (Keyfitz and Flieger 1990; China Statistical Yearbook 2003). Studies of the value of a statistical life year in rich and poor nations suggest that the value of an additional year of life in China is about 3.5 times per capita income (see, e.g., Murphy and Topel 2002; Viscusi and Aldy 2003). Hence, the value of the unmeasured improvements in life expectancy may have been high enough to raise the rate of economic growth between 1980 and 2000 by about 60 percent. If the true growth of GDP between 2000 and 2040 is 13 percent instead of 8 percent, then the true size of the Chinese economy in 2040 will be about 6 times the size of the measured economy. Of course, if both the United States and China similarly neglect changes of quality in their measurements, the relative ranking of the two economies may not be changed significantly.

\section{Will Political Instability Undermine Economic Growth?}

So far I have focused purely on economic issues. Some analysts argue that political instability is a serious impediment to China's ability to maintain high rates of economic growth. Several scenarios have been outlined in which political factors could thwart economic goals. Some of these scenarios begin with an economic breakdown brought on by a sharp cyclical 
downturn that would raise unemployment and undermine a precarious social stability. Others warn that a growing social unrest has been brought on by the financial problems and inefficiencies of the state-owned enterprises. These problems have not only led to rising urban unemployment but have also resulted in the failure to pay promised wages, pensions, health-care allowances, and housing allowances (Bremmer 2005; Chaohua 2005). Still others warn of an impending breakdown in the banking system, which is beset by a huge burden of nonperforming loans, a breakdown that could undermine the microeconomic stability of the economy (Garnaut and Song 2004).

Other threats to stability that have been observed include: widespread corruption; internal power struggles; bubbles in real estate, international trade, and steel (among other products); inequality between the urban and rural areas, between the coastal and interior provinces, between the highly educated elites and poorly educated masses, and between the Han majority and the ethnic minorities. One unique warning singles out the sharp rise in the sex ratio concentrated at ages 15-34, which, it is argued, will translate into high rates of crime and violence and may promote concubinage. Some single out international tensions, particularly over Taiwan, which divert the attention of the leadership from their growth objectives (Pei 2005; Bradsher 2004; Dunphy 2004, Hu 2000; Lim 2004; Business Asia 2002; McGregor 2004; Wilson 2004; EIU ViewsWire 2004).

When speculating about the future, the range of possible scenarios is virtually unlimited. The point at issue is not what might occur, but what is likely to occur. Moreover, many of the problems singled out are of long standing, such as the inefficiency of many state-owned enterprises. While these SOEs may be a drag on the economy, China has nevertheless been able to grow at over 8 percent per capita for a quarter of a century. The idea that these inefficient 
firms will suddenly go bankrupt is far-fetched. The policy of the State Council has been to gradually phase them out or to reorganize them on a profitable basis so as not to sharply increase unemployment. Not only does the government have the finances needed to continue subsidizing inefficient firms if it chooses to do so for economic or political reasons, but the burden of these subsidies will also gradually diminish, because the share of the industrial output supplied by these underperforming SOEs will gradually decline and the burden of a given level of subsidies will rapidly diminish with the economy growing so rapidly.

These points also apply to the problem of the state banks. Although the proportion of nonperforming loans may be about 35 percent, China is not in immediate danger of a collapse of its banking system. It is within the power of the government to remove this burden. The banks originally became saddled with the bad paper because the government obliged the banks to finance unprofitable SOEs. The inefficiencies and distortions in the economy produced by banking policies have been relieved by the large injection of foreign direct investment, encouraged by government policy, which has also facilitated the transfer of advanced technologies to China. With direct investment going largely into large-scale industry, the banks have been able to supply part of the capital needed by small-scale enterprises (Lin, Cai, and $\mathrm{Li}$ 2003; Fan 2005). Movements in the direction of more effectively using the monetary system to manage business cycles, and contemplated reforms in capital markets, should also alleviate economic distortions. For example, the government recently restructured two of the four largest state-owned banks to bring their capital position up to international standards. Most important, perhaps, is the very low level of government indebtedness (less than a fifth of GDP), which gives the State Council leeway to pursue needed stabilization policies, including a rapid restructuring 
of the banking system, instead of the gradual policy of reform it is currently pursuing (Lin, Cai, and Li 2003; Fan 2005).

Although there are disagreements about economic policy among the top leaders, the proposition that China should continue to transform itself into a market economy is not at issue. Nor is there disagreement over the policy of promoting increasing autonomy in economic decisions as a lever of rapid economic growth. As many analysts have pointed out, the government is unified around a policy that has been called "market preserving federalism." This Chinese form of federalism limits the central government's control over economic decision making, promotes creative competition among local governments, constrains rent seeking, and provides an array of incentives to induce creative local enterprises. This type of federalism is also apparent in the design of the tax system, which has been called "fiscal federalism," and which is aimed at preventing taxation from stifling economic growth. In the tax reform of 1994, the central government limited its primary administration to VAT and taxes on centrally owned enterprises. It also set up local tax bureaus under the direction of local governments to supervise income taxes. While much remains to be done in the design of the fiscal system, especially with respect to narrowing regional inequalities, these issues are on the leadership's agenda of needed reforms. The central leadership is also aware of the danger that local autonomy may move in counterproductive ways that promote rent seeking, moral hazard, and other forms of corruption, and that it must monitor performance and penalize corruption where possible. The successful unfolding of autonomy requires a center strong enough to integrate national and local goals, to discipline local authorities whose corrupt practices threaten the progress of reform, and to provide rewards to those who advance it (Lin, Cai, and Li 2003; Bahl and Martinez-Vazquez 
2003; Blanchard and Shleifer 2000; Montinola, Qian, and Weingast 1996; Krug, Zhu, and Hendrischke 2003).

Some analysts argue that unless China permits competing political parties, powerful pressures will build up between the provinces and the center that will undermine political stability and thwart continued high rates of economic growth. Others argue that the unsolved inequalities have also built up pressures at the grass roots that threaten to become unmanageable (Goldstone 1995; Ohman 1995; Esarey 2002). Other issues stressed by analysts include mounting environmental hazards, lagging development of public health programs, and endemic corruption (Shambaugh 2000; Chapman 2002).

The difficulty with these arguments is that they assume that the leaders of the CCP and the State Council are unaware of these problems. The leaders are quite well aware that the successes of their growth policies have weakened the central government's control over daily life and access to information. Indeed, one purpose of the reforms was to promote creativity at the local level by promoting local initiative and by encouraging the entry of global firms into the Chinese market in order to facilitate new ideas and technologies. Moreover, critiques of current policies that hamper economic growth are encouraged, although competitive political parties are prohibited. Debates over governmental policies at all levels are as vigorous and wide-ranging at the meetings of the Chinese Economists Society as they are at the American Economic Association.

The leaders of the CCP have responded to the changing economic and social conditions by changing the central goal of the $\mathrm{CCP}$ and by co-opting the elites who are at the forefront of China's economic and social transformation. This process of adaptation is reflected in the new slogan of the CCP, "Three Represents," introduced by Jiang Zemin in the spring of 2000 to 
replace the previous slogan of "Three Revolutionary Classes" (peasants, workers, and soldiers). The new slogan portrays the CCP as: (1) the embodiment of society's most advanced productive forces; (2) the promoter of an advanced culture; and (3) representing the needs and interests of the great majority of the Chinese population. To extend its connections with the elites who are bringing about the transformation of China, the $\mathrm{CCP}$ encouraged the formation of a wide array of new business and professional societies with strong ties to the state. It also transformed the membership of the CCP, bringing into its fold the technocratic leaders of business, social, and intellectual life. During the two decades following 1982, the proportion of the Central Committee members holding college degrees increased from a little over half to nearly 99 percent (Dickson 2003a and b).

The $16^{\text {th }}$ Congress of the CCP, which met in November 2002, made provincial leaders the most prominent group in the Politburo, representing 42 percent of its membership. By contrast, the military represented only 8 percent of the Politburo, and central party institutions accounted for 25 percent. The balance of the Politburo membership came from Shanghai political circles or from institutions other than provincial leaderships or central government institutions. Given the dominant role of provincial leaders in the shaping of national policy, it makes little sense to dwell on the possibility of a conflict between the national and provincial leaders, especially when many of the central leaders came from provincial posts (Bo 2004).

Some analysts argue that leaders of the CCP and the State Council are out of touch with public opinion. However, the weight of evidence contradicts that view. Local and provincial governments have been using polling techniques to determine public opinion on an array of economic and social issues since the late 1980s. Academic critics of government policies abound and interactions between these critics and top government leaders are numerous. The range of 
problems raised by respondents to surveys mirrors the complaints of academic critics and foreign analysts, including widespread corruption, increasing inequality, persistent unemployment, burdensome taxes, and unpaid pensions. Nevertheless, the polls also reveal majority support for the central government and overwhelming belief that the courts, the press, and government institutions will be responsive to their grievances (Pei 2001; Lin et al. 2002; China Newsweek 2005). ${ }^{4}$

Popular confidence in the government reflects the widespread belief among the Chinese that their living conditions have improved (67 percent better, 12 percent worse, 20 percent no change). The level of confidence about whether living conditions will continue to improve is similar. According to another poll, optimism about the future is slightly higher in rural areas (75 percent) than in the cities (68 percent). Hence, it is not surprising that political reform is quite limited, although there is an expectation that the government will gradually improve legal and governmental institutions. This generally favorable view of government not only reflects the pragmatic responses of leaders at all levels of government to grievances, but also the frequent intervention of the central government with local officials when they are too slow to respond to complaints. It also reflects the rapid increases in income experienced by the great majority of households for more than a quarter of a century (Fewsmith 2003). ${ }^{5}$

This combination of widely shared economic advances and governmental attention to public opinion, especially with respect to grievances, is a formula for continued political stability. One indication of the stability of the regime and the self-confidence of its leaders is its successful bid for the 2008 Olympic Games. Another is its encouragement of Chinese students to enroll in American and European universities. The gradual loosening of constraints on expression in China is likely to continue over the next several decades. Whether or not these 
developments lead to a multiparty system of the American type remains to be seen. However, the government's responsiveness to popular concerns indicates that political stability is likely to remain at the level required for continued long-term economic growth. 


\section{Notes}

1. Discussions of economic impediments that may foil the growth targets of China are summarized in Shane 2005; Zakaria 2005; Morrison 2005; R. Wang 2005; Economist 2004a, 2004b, 2005a; Prasad 2004.

2. The disaggregation shown in Table 1 is based on data from the China Statistical Yearbook 2003, pp. 26, 27, 313. In the absence of a GDP deflator, the retail fixed-base price index was used to obtain real GDP. Because the differential approximation shown

in equation (1) does not quite add up to $\frac{*}{Y}$, the sum of the terms on the right-hand side of the equation was used as the denominator when computing the contribution of changes in the LFPR, in inter-industry shifts in the labor force, and in within-sector productivity to the overall change in per capita income.

3. The relative index for other G-8 countries reporting data were somewhat different from those shown for the United States in Table 2, but not materially so. Their use would not materially change the analysis. I prefer the U.S. figures as reported in Table 2 because it is likely that even they underestimate the impact of labor-augmentation on Chinese economic growth. The data reported by OECD for 6 of the G-8 countries for 1997, 1998, or 1999 are as follows:

\begin{tabular}{lcccccc}
\hline & Canada & France & Germany & Italy & UK & U.S. \\
\hline Less than 12th grade & 100 & 100 & 100 & 100 & 100 & 100 \\
High-school graduate & 120 & 119 & 128 & 172 & 154 & 149 \\
B.A. or higher degree & 183 & 201 & 201 & - & 263 & 269 \\
\hline
\end{tabular}

Source: Sherman, Honegger, and McGivern 2003, Table A31.

The values of the U.S. index in this table differ from those in Table 2 for several reasons. The values here are based on average income over both sexes rather than the median income for men only. The age range here excludes persons aged 65 and over. The years used here are 1997, 1998, or 1999 rather than 2000. But the most important factor is that the base here is less than twelfth grade rather than less than ninth grade. It should be noted that in Table 2, the ratio of the income of persons with college degrees to those with high school degrees is 173 . In this note it is 181 .

4. Other interesting discussions of political stresses and responses include Huang 1995; Chapman 2002; Gong 2005; D. Wang 2005; and Bremmer 2005.

5. It is also worth noting the distinction made by Fareed Zakaria between liberal democracies, illiberal democracies, and liberalizing autocracies. Liberal democracies are not only marked by contested elections, but also by governments that seek to protect the autonomy and dignity of individuals against coercion, create checks on the power of various branches of government, and establish equality under law. Illiberal democracies have contested elections but the elected governments use their power to repress speech and assembly and to restrict economic and social behavior. Liberalizing autocracies have 
one-party systems but have permitted individuals limited political rights and have improved the spheres of economic, social, and civil rights. He argues that most East Asian governments today "are a mix of democracy, liberalism, capitalism, oligarchy, and corruption-much like Western governments circa 1900" (Zakaria 1997, 28; cf. Zakaria 2003. See also Economist 2005b). 


\section{FIGURE 1}

\section{Level and Growth Equations}

(1) $\bar{Y}=\rho\left(\lambda_{a} W_{a}+\lambda_{i} W_{i}+\lambda_{s} W_{s}\right)$

(2) $\stackrel{\stackrel{*}{Y}}{Y}=\sigma_{a}\left(\ddot{\lambda}_{a}+\stackrel{*}{W}_{a}\right)+\sigma_{i}\left(\ddot{\lambda}_{i}+\stackrel{*}{W}_{i}\right)+\sigma_{s}\left(\ddot{\lambda}_{s}+\stackrel{*}{W}_{s}\right)+\stackrel{*}{\rho}$

where

$$
\begin{aligned}
\bar{Y} & =\text { per capita income } \\
\rho & =\text { the labor force participation rate } \\
\lambda_{a}, \lambda_{i}, \lambda_{s}= & \text { the agricultural, industrial, and service shares of the labor force } \\
W_{a}, W_{i}, W_{s}= & \text { output per worker in agriculture, industry, and services } \\
*= & \begin{array}{l}
\text { an asterisk over a variable indicates the growth rate of that } \\
\text { variable }
\end{array} \\
\sigma_{a}, \sigma_{i}, \sigma_{s}= & \begin{array}{l}
\text { the mid-period share of income originating in agriculture, } \\
\text { industry, and services }
\end{array}
\end{aligned}
$$




\section{TABLE 1}

Values of Variables and Weights Used in Growth Decomposition for 1978-2002

\section{Variable or Weight}

\begin{tabular}{cc} 
& 1978-2000 \\
\hline$\stackrel{*}{Y}$ & 8.4 \\
$\lambda_{a}^{*}$ & -1.4 \\
$W_{a}^{*}$ & 5.7 \\
$\stackrel{*}{\lambda}_{i}$ & 0.9 \\
$W_{i}^{*}$ & 6.2 \\
$\lambda_{s}^{*}$ & 3.6 \\
$W_{s}^{*}$ & 4.5 \\
$\stackrel{*}{\rho}^{*}$ & 1.3 \\
$\sigma_{a}$ & 0.218 \\
$\sigma_{i}$ & 0.496 \\
$\sigma_{s}$ & 0.286
\end{tabular}


TABLE 2

\begin{tabular}{|c|c|c|}
\hline Country & Period & Growth Rate \\
\hline India $^{a}$ & 1980-1997 & 2.3 \\
\hline Indonesia $^{\mathrm{a}}$ & 1980-1997 & 1.7 \\
\hline Japan $^{\mathrm{a}}$ & 1980-1997 & 4.1 \\
\hline Korea (South) ${ }^{\mathrm{a}}$ & 1980-1997 & 6.8 \\
\hline Malaysia $^{a}$ & 1980-1997 & 3.7 \\
\hline Taiwan-China $^{\mathrm{d}}$ & $1985-2003$ & 3.9 \\
\hline Thailand $^{\mathrm{a}}$ & 1980-1997 & 2.3 \\
\hline France $^{\mathrm{a}}$ & 1980-1997 & 5.5 \\
\hline Germany $^{\mathrm{a}}$ & $1980-2000$ & - \\
\hline Italy $^{\mathrm{b}}$ & 1980-2000 & 5.2 \\
\hline United Kingdom ${ }^{\mathrm{b}}$ & $1980-2000$ & 3.4 \\
\hline United States ${ }^{c}$ & 1958-1996 & 3.2 \\
\hline
\end{tabular}

Sources: (a) World Development Report 2000/2001, Table 8.

(b) World Bank, World Development Indicators (https://publications.worldbank.org/subscriptions/WDI)

(c) Jorgenson and Stiroh 2000, Table 2

(d) Asian Development Bank 2004. 
TABLE 3

Gross Enrollment Ratios

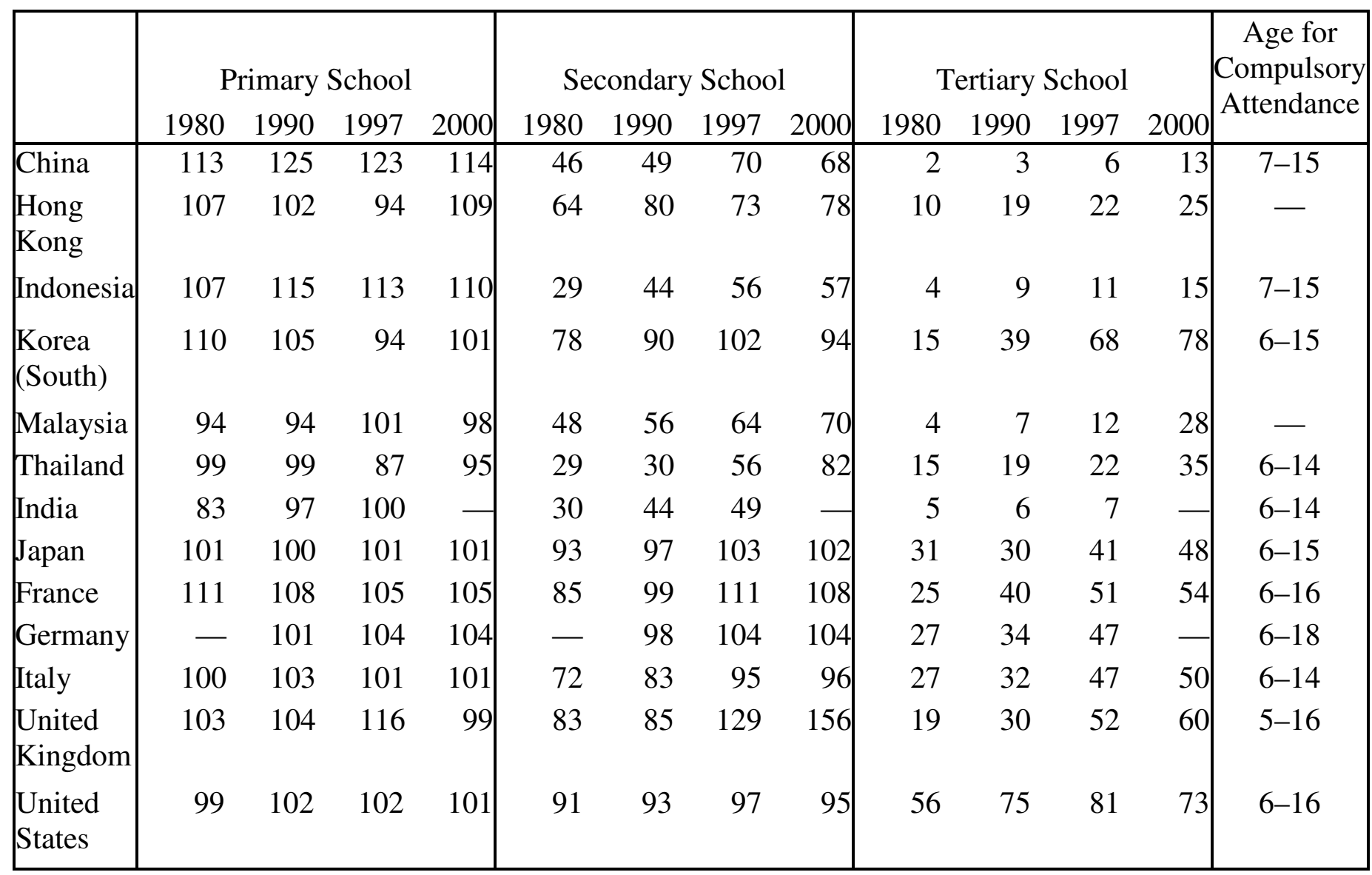

Source: U.S. Department of Education, National Center for Education Statistics 2004, Table 394. http://nces.ed.gov/programs/digest/d04/tables/xls/tabn394.xls

Note: Gross enrollment ratios are equal to the total enrollment of all ages in the school level divided by the population of the specific ages that correspond to the specific age groups that correspond to the school level. Ratios may exceed 100 because of the students outside the relevant age range. 


\section{FIGURE 2}

\section{A Labor-Augmenting Production Function}

(3) $Q=A\left(L \gamma_{L}\right)^{\alpha}\left(K \gamma_{K}\right)^{1-\alpha}$

or (4) $\frac{Q}{L}=\left[A \gamma_{L}^{\alpha} \gamma_{K}^{1-\alpha}\right]\left(\frac{K}{L}\right)^{1-\alpha}$

$$
\stackrel{*}{Q}-\stackrel{*}{L}=\left[\stackrel{*}{A}+\alpha \gamma_{L}^{*}+(1-\alpha) \gamma_{K}^{*}\right]+(1-\alpha)(\stackrel{*}{K}-\stackrel{*}{L})
$$

where

$$
\begin{aligned}
Q & =\text { output } \\
A & =\text { an index of total factor productivity } \\
L & =\text { the labor input } \\
\gamma_{L} & =\text { an index of labor augmentation } \\
\gamma_{K} & =\text { an index of capital augmentation } \\
* & =\text { an asterisk indicates the growth rate of a variable } \\
\alpha & =\text { the labor share of income } \\
1-\alpha & =\text { the capital share of income }
\end{aligned}
$$


TABLE 4

Measuring the Likely Impact of Labor Augmentation through Secondary and Higher Education on the Growth Rate of Per Capita Income

\begin{tabular}{lc}
\hline Index of the Relative Productivity of Different Educational Endowments & Index \\
\hline Less than ninth & 100 \\
High school graduate & 179 \\
Bachelor's or higher degree & 310 \\
\hline
\end{tabular}

Estimated values for

$\alpha$ 0.6

$\ddot{\gamma}_{L 2}$ if secondary enrollment ratios reach 100 in 20 years $(\%)$

1.8

$\mathscr{\gamma}_{L 3}$ if tertiary enrollment ratios reach 25 in 20 years $(\%)$

7.4

$\ddot{\gamma}_{L 3}$ if tertiary enrollment ratios reach 50 in 20 years $(\%)$

11.2

$\alpha$ is from Young 2000, Table XXIII. Index values are computed from median U.S. income by educational attainment (U.S. Department of Education, National Center for Education Statistics 2001, Table 383. http://nces.ed.gov/programs/digest/ d01/ dt383.asp). 


\section{References}

Asian Development Bank. 2004. Key indicators 2004: Poverty in Asia: Measurement, estimates, and prospects. Manila, Philippines: Asian Development Bank.

Bahl, Roy, and Jorge Martinez-Vazquez. 2003. Fiscal federalism and economic reform in China. Georgia State University International Studies Program, Working Paper No. 03-13.

Blanchard, Olivier, and Andrei Shleifer. 2000. Federalism with and without political centralization. China versus Russia. Typescript, MIT. http://econ-www.mit.edu/faculty/ download_pdf.php?id=818.

Bo, Zhiyue. 2004. The $16^{\text {th }}$ Central Committee of the Chinese Communist Party: Formal institutions and factional groups. Journal of Contemporary China 13: 223-56.

Bradsher, Keith. 2004. Is China the next bubble? New York Times, 18 January 2004. http://proquest.umi.com/pqdlink?index $=218 \&$ did $=525776671 \&$ SrchMode $=3 \&$ sid $=1 \&$ Fmt $=3$ $\&$ VInst=PROD \&VType=PQD\&RQT $=309 \&$ VName=PQD $\& T S=1123083139 \&$ clientId $=133$ 92\&aid=1.

Bremmer, Ian. 2005. Can China handle threats to growth and stability? Financial Times. 20 March 2005.

Business Asia. 2002. Fog on the horizon. 25 March 2002.

Chaohua, Wang. 2005. Nothing to lose but their power. New Statesman. 1 January 2005.

Chapman, Roger E. 2002. Review of Is China unstable? Assessing the factors, ed. David Shambaugh. H-US-Japan, October 2002. http://www.h-net.msu.edu/.

China Newsweek. 2005. Opinion polls to link government and public. Translated by Li Shen and Yuan Fang for China.org.cn, 27 January 2005. http://www.china.org.cn/english/2005/Jan/ 119018.htm.

China Statistical Yearbook 2005. Beijing: China Statistics Press.

China Statistical Yearbook 2003. Beijing: China Statistics Press.

Colvin, Geoffrey 2005. Can Americans compete? Fortune 25 July 2005. www.fortune.com/fortune/articles/0,15114,1081269,00.html

Cutler, David M., and Mark McClellan. 2001. Is technological change in medicine worth it? Health Affairs 20, no. 5: 11-29.

Dickson, Bruce J. 2003a. Threats to Party supremacy. Journal of Democracy 14: 27-35.

Dickson, Bruce J. 2003b. Whom does the Party represent? From "three revolutionary classes" to "three represents." American Asian Review 21: 1-24. 
Dunphy, Stephen H. 2004. The China bubble. Seattle Times, 1 February 2004, Sunday fourth edition.

Economist. 2004a. A great wall of waste. 21 August 2004.

Economist. 2004b. Where are the patients? 21 August 2004.

Economist. 2005a. China and water: Drying up. 21 May 2005.

Economist. 2005b. Winning is only half the battle. 23 March 2005.

EIU ViewsWire. 2004. China politics: Rising U.S. tensions. 2 April 2004.

Esarey, Ashley W. 2002. Reconsidering Weingast market-preserving federalism in contemporary China. http://www.columbia.edu/ as48/Comparative\%20Federalism_files/MPF\%2002-0204.pdf.

Fan, Gang. 2005. China's tough choices. Global Agenda 2005, 140-41.

Fewsmith, Joseph. 2003. China's domestic agenda: Social pressures and public opinion. China Leadership Monitor, no. 6: 48-64.

Fogel, Robert William. 2000. The fourth great awakening and the future of egalitarianism. Chicago: University of Chicago Press.

Fogel, Robert William. 2004a. The escape from hunger and premature death, 1700-2100: Europe, America, and the Third World. New York: Cambridge University Press.

Fogel, Robert William. 2004b. High performing Asian economies. NBER Working Paper No. 10752.

Garnaut, Ross and Ligang Song, eds. 2004. China's third economic transformation: the rise of the private economy. London: RoutledgeCurzon.

Goldstone, Jack A. 1995. The coming Chinese collapse. Foreign Policy, no. 99: 35-52.

Gong, Xiaobing. 2005. Reforms in China: Enhancing the political role of Chinese lawyers (includes remarks by Veron Hung). Translated by Victorien Wu and Veron Hung. Presented at a seminar sponsored by the Carnegie Endowment for International Peace and the Asia Foundation, 2 June 2005. http://www.carnegieendowment.org/events/index.cfm?fa= eventDetail\&id=781\&\&prog=zch.

Heckman, James J. 2005. China's human capital investment. China Economic Review 16: 50-70.

Hu, Fred. 2000. Drifting apart. World Link 13, no. 5: 24-26.

Huang, Yasheng. 1995. Why China will not collapse. Foreign Policy, no. 99: 54-68. 
Johnson, D. Gale. 2000. Agricultural adjustment in China: Problems and prospects. Population and Development Review 26:319-34.

Jorgenson, Dale W., and Kevin J. Stiroh. 2000. U.S. economic growth at the industry level. American Economic Review 90: 161-67.

Keyfitz, Nathan and Wilhelm Flieger. 1990. World population growth and aging. Chicago: University of Chicago Press.

Krug, Barbara, Ze Zhu, and Hans Hendrischke. 2003. China's emerging tax regime: Devolution, fiscal federalism, or tax farming? Erasmus Research Institute of Management Report Series Reference No. ERS-2004-113-ORG. http://papers.ssrn.com/sol3/ papers.cfm?abstract_id= 650830.

Lim, Paul J. 2004. White-hot China. U.S. News \& World Report. 15 March 2004.

Lin, Gang, Martin King Whyte, Jie Chen, Edward Friedman, and Yongming Zhou. 2002. China's "credibility gap": Public opinion and instability in China. Asia Program Special Report no. 104. Woodrow Wilson International Center for Scholars: Washington, D.C.

Lin, Justin Yifu, Fang Cai, and Zhou Li. 2003. The China miracle: Development strategy and economic reform. Sha Tin N. T., Hong Kong: Chinese University Press for the Hong Kong Centre for Economic Research and the International Center for Economic Growth.

Lin, Justin Yifu, and Yingyi Tsai. 2004. Reform and development in China: A new institutional economics perspective. Seoul Journal of Economics 17, no. 3 (special issue): 335-81.

McGregor, Richard. 2004. China politics: Clashes in China raise doubt over state control. EIU Views Wire. 3 November 2004. http://proquest.umi.com/pqdweb?index=46\&did=759809111 $\&$ SrchMode $=1 \&$ sid $=3 \&$ Fmt $=3 \&$ VInst=PROD $\&$ VType $=$ PQD $\&$ RQT $=309 \&$ VName=PQD \& $\mathrm{TS}=1123000230 \&$ clientId=13392.

Montinola, Gabriella, Yingyi Qian, and Barry R. Weingast. 1996. Federalism, Chinese style: The political basis for economic success. World Politics 48: 50-81.

Morrison, Wayne M. 2005. China's economic conditions. CRS Issue Brief for Congress, updated 25 April 2005. http://fpc.state.gov/documents/organization/45465.pdf.

Murphy, Kevin M., and Robert H. Topel. 2003. The economic value of medical research. In Measuring the gains from medical research: An economic approach, ed. Kevin M. Murphy and Robert H. Topel. Chicago: University of Chicago Press.

Newcomb, Amelia. 2005. China goes to college-in a big way. Christian Science Monitor, 29 July 2005, Vol 29 Issue 172, 1-4. http://www.csmonitor.com/2005/0729/p01s01-woap.html.

U.S. Department of Education, National Center for Education Statistics. 2002. Digest of education statistics, 2001, NCES 2002-130. Washington, D.C.: U.S. Department of Education. http://nces.ed.gov/pubsearch/pubsinfo.asp?pubid=2002130. 
Nordhaus, William D. 2003. The health of nations: The contribution of improved health to living standards. In Measuring the gains from medical research: An economic approach, ed. Kevin M. Murphy and Robert H. Topel. Chicago: University of Chicago Press.

Ohman, Jack. 1995. Post-Deng China: The possible outcomes. Foreign Policy, no. 99: 53.

Pei, Minxin. 2001. Cracked China. Review of 2001 Shehui lanpishu: Zhongguo shehui xingshi fengxi yu yuce (Social blue book 2001: Analysis and forecasting of social conditions in China), ed. Ru Xin, Lu Xueyi, and Shan Tianlun. Foreign Policy, no. 126: 78-80.

Pei, Minxin. 2005. Dangerous denials: China's economy is blinding the world to its political risks. Foreign Policy no. 146: 56-58.

Prasad, Eswar, ed. 2004. China's growth and integration into the world economy: Prospects and challenges. International Monetary Fund Occasional Paper 232. Washington, D.C.: International Monetary Fund. http://www.imf.org/external/pubs/ft/op/232/op232.pdf.

Shambaugh, David. 2000. The modern Chinese state. New York: Cambridge University Press.

Shane, Matthew. 2005. China's economic growth faces challenges. Amber Waves 3, no. 1: 3. http://www.ers.usda.gov/AmberWaves/February05/Findings/ChinaEconomicGrowth.htm.

Sherman, Joel D., Steven D. Honegger, and Jennifer L. McGivern. 2003. Comparative indictors of education in the United States and other G-8 countries: 2002, NCES 2003-026. Washington, D.C.: U.S. Department of Education, National Center for Health Statistics. http://scsvt.org/resource/global_ed_compare_2002.pdf.

Statistical Abstract of the United States: 2005. 2005. Washington, D.C.: U.S. Census Bureau.

Viscusi, W. Kip and Joseph E. Aldy. 2003. The value of a statistical life: a critical review of market estimates throughout the world. NBER Working Paper w9487.

Wang, Dan. 2005. The old man of Tiananmen. Wall Street Journal, 18 January 2005.

Wang, Mengkui. 2005. Growth model needs modification. China Daily, 11 May 2005. http://www.chinadaily.com.cn/english/doc/2005-05/11/content_441002.htm.

Wang, Robert. 2005. China's economic growth: Source of disorder? Foreign Service Journal 82, no. 5: 18-23.

Wilson, James Q. 2004. Sex matters. Review of Bare branches, by Valerie M. Hudson and Andrea M. den Boer. Wall Street Journal, 13 July 2004.

World Development Bank. 2001. World development report 2000/2001: Attacking poverty. New York: Oxford University Press.

Young, Alwyn. 2000. Gold into base metals: Productivity growth in the People's Republic of China during the Reform Period. NBER Working Paper No. 7856. 
Zakaria, Fareed. 1997. The rise of illiberal democracy. Foreign Affairs 76, no. 6: 22-43.

Zakaria, Fareed. 2003. The future of democracy: Illiberal democracy at home and abroad. New York: W. W. Norton.

Zakaria, Fareed. 2005. Does the future belong to China? Newsweek, 9 May 2005. 